\title{
The abundance of canopy arthropods in South Sumatra (Indonesia) freshwater swamp main and ratooned rice applied with bioinsecticides and synthetic insecticide
}

\author{
GHANNI PRABAWATI ${ }^{1}$, SITI HERLINDA ${ }^{1,2,3 \vee}$, YULIA PUJIASTUTI ${ }^{1,2,3}$ \\ ${ }^{1}$ Crop Sciences Graduate Program, Faculty of Agriculture, Universitas Sriwijaya. Jl. Padang Selasa No. 524, Bukit Besar, Palembang 30139, South \\ Sumatra, Indonesia \\ ${ }^{2}$ Department of Plant Pests and Diseases, Faculty of Agriculture, Universitas Sriwijaya. Jl. Raya Palembang-Prabumulih, Km 32, Indralaya, Ogan Ilir \\ 30662, South Sumatra, Indonesia. Tel.: +62-711-580663, Fax.: +62-711-580276, "email: sitiherlinda@unsri.ac.id \\ ${ }^{3}$ Research Center for Sub-optimal Lands (PUR-PLSO), Universitas Sriwijaya. Jl. Padang Selasa No. 524, Bukit Besar, Palembang 30139, South Sumatra, \\ Indonesia
}

Manuscript received: 5 August 2019. Revision accepted: 11 September 2019.

\begin{abstract}
Prabawati G, Herlinda S, Pujiastuti Y. 2019. A comparative study on the arboreal arthropod abundance of rice fields between applied with fungal bioinsecticides and abamectin in the freshwater swamp of South Sumatra, Indonesia (Study case in the main and ratoon rice fields). Biodiversitas 20: 2921-2930. Ratoon rice has been cultivated by local farmers in South Sumatra and can be a source of habitat and niches for the main rice arthropods. The study aimed to compare the abundance of arthropods between main and rationed rice field applied with fungal bioinsecticides and abamectin. This study used bioinsecticides from fungi of Beauveria bassiana, Metarhizium anisopliae, and Cordyceps militaris and control using abamectin. Arboreal arthropods sampled using a sweep net. The abundance of arthropods in the main rice tends to be higher than in ratoon. Spiders found during the two rice seasons were Araneidae, Linyphiidae, Lycosidae, Oxyopidae, Salticidae, Theridiidae, Tetragnathidae, Theridiosomatidae, while predatory insects found were Mantidae, Coenagrionidae, Staphylinidae, Anthicidae, Latridiidae, Formicidae, Coccinellidae, Coccinellidae, Tettigoniidae, Miridae, Carabidae. The fungal bioinsecticides did not reduce the predatory arthropod abundance but the abamectin caused a decrease in the abundance of all guilds. The most drastic decrease was found in web-building spiders. The movement of hunting spiders and the predatory insects of the main to ratoon rice was faster than that of web-building spiders. The existence of ratoon rice could become habitats and niches for arthropods from the main rice. For this reason, controlling the herbivore insects could use bioinsecticides derived from entomopathogenic fungi.
\end{abstract}

Keywords: Abamectin, arthropods abundance, bioinsecticides, rice field, South Sumatra

\section{INTRODUCTION}

Wetlands in Indonesia consist of freshwater swamps and tidal lowlands. Freshwater swamps are a wetland ecosystem formed by flooded throughout the year by river flow or rain, whereas tidal lowlands are inundated due to the tide flow from the sea. The area of wetlands in Indonesia reaches 39.6 Mha, of which the widest areas spread over Sumatra Island (11.9 Mha), Kalimantan (12.2 Mha), and Papua (11.8 Mha), the rest spread in Java (1.9 Mha), Sulawesi (1.2 Mha), Maluku (0.5 Mha) ), and BaliNusa Tenggara (0.2 Mha) (Margono et al. 2014). Freshwater swamps scattering in Indonesia reach 9.2 Mha (Mulyani and Sarwani 2013)

Freshwater swamps in South Sumatra are flooded starting from November to April or May every year. In freshwater swamp, local farmers usually grow rice in April or May and harvest in August or September so that they only plant rice once a year (Herlinda et al. 2018a). While in shallow freshwater swamps, they grow rice twice a year. For rather deep and deep freshwater swamps, local farmers re-grow the rice stumps out of the main rice so that they germinate and return to a production called ratoon rice or secondary rice (Lakitan et al. 2019). In tidal lowlands of
South Sumatra, ratoon rice cultivation is commonly carried out (Herlinda et al. 2019).

The presence of ratoon rice in the freshwater swamps can become habitats and niches for the main rice arthropods. During this time, planting rice once a year in freshwater swamps leads to a break in the life cycle of arthropods, especially generalist predators in rice (Herlinda et al. 2018a) so that in the following planting season, the predators get late to colonize the rice fields and cause an increase in herbivore population (Settle et al. 1996). The predators get decreased when the next season the rice fields are applied to synthetic insecticide (Lopes et al. 2017; Ngin et al. 2017; Herlinda et al. 2019).

The freshwater swamp rice fields of South Sumatra generally do not use synthetic pesticides (Siaga et al. 2019). However, at the moment the local farmers start to grow rice twice a year, and some start to cultivate ratoon rice causing the insect pests population increases on the crop. As a result, they start to control it using synthetic insecticides (Herlinda et al. 2019). The phenomenon of changes in insect pest populations tends to be followed by changes in the abundance of arthropods in other guilds (Herlinda et al. 2018a). There are not many local farmers in South Sumatra using bioinsecticides derived from 
entomopathogenic fungi to control insect pests. Many studies have shown that entomopathogenic fungi can kill rice insect pests. For example, Beauveria bassiana effectively kills brown planthopper (Sumikarsih et al. 2019). Filtrate $B$. bassiana culture is very toxic to Spodoptera litura larvae (Ayudya et al. 2019). Isolates of B. bassiana and Metarhizium anisopliae are found in wetlands in South Sumatra (Safitri et al. 2018). In addition, in wetlands of South Sumatra and Central Kalimantan, an entomopathogenic fungus is found, Cordyceps militaris which attacks fire caterpillars (Setothosea asigna) in oil palms. C. militaris is not found to attack the insect pests of rice. It can produce beauvericin, a toxin for insect pests (Rachmawati et al. 2018). While abamectin is an insecticide with broad-spectrum activity (Ananiev et al. 2002) and often used by farmers in Indonesia to control a brown planthopper (BPH), Nilaparvata lugens but the abamectin reduced the parasitism level and the number of BPH parasitoid (Anagrus nilaparvatae) progeny emerged (Sasmito et al. 2017). This study aimed to compare the abundance of arthropods in main and ratoon rice applied with bioinsecticides derived from entomopathogenic fungi and abamectin.

\section{MATERIALS AND METHODS}

The field experiment has been carried out in the Pelabuhan Dalam Village of Pemulutan Subdistrict of Ogan Ilir District, South Sumatra Province, Indonesia which was the center of freshwater swamps. The experiments began from May to August 2018 for the main rice. Then after the harvest, it continued to secondary or ratooning rice until November 2018. Identification of arthropods was started from November 2018 to March 2019. Bioinsecticide used in this study derived from $B$. bassiana, $M$. anisopliae, $C$. militaris, while abamectin is a commercial insecticide used as a control. The area of each treatment plot was $120 \mathrm{~m}^{2}$, which was repeated five times. The distance between the treatments was $10 \mathrm{~m}$.

\section{Preparation of main and ratoon rice}

The main rice preparation was conducted through tillage, planting, and maintenance of rice. Before the soil was processed, the land was cleared of weeds, and then the soil tillage was processed using uncovered plows and rakes. Water was regulated using a pump so that the soil became sludgy, and it was added organic manures with a dose of 1 ton.ha ${ }^{-1}$. After the soil and manure were well mixed, it was left that way for 7-14 days before the rice was planted.

Meanwhile, the nursery was prepared and the seeds used were certified as purple labels, namely the Mekongga variety with a dose of $50 \mathrm{~kg} \cdot \mathrm{ha}^{-1}$. The seeds of rice were sown according to the traditions of local farmers namely using the method of samir and if the seedlings were 7 days old they were transplanted into the rice fields. The rice seedlings transplanted were encoded as many as 2 stems per hole with a spacing of type $2: 1$ jajar legowo planting system $(12.5 \mathrm{~cm}$ x $25 \mathrm{~cm}$ x $50 \mathrm{~cm})$.
Maintenance of rice was carried out through pumping, weeding, and fertilizing compost extract. Embedding of dead rice was conducted seven days after transplanting (DAT). Water management was carried out by utilizing river water tides and pumping. Land sanitation was carried out on vegetative and generative stages by weeding weeds using sickles. Fertilization was carried out with liquid compost extract from shrimp skin, which was made following the method of Suwandi et al. (2012). The compost extract was applied every two weeks starting from

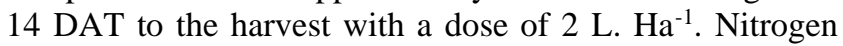
fertilizer was applied when rice was 30 DAT at a dose of $100 \mathrm{~kg} \cdot \mathrm{ha}^{-1}$.

Preparation of ratoon rice was carried out in a specific way. The stems of main rice that was just (1-2 days) manually harvested using sickles was then cut into 3 to 5 $\mathrm{cm}$ from the ground using a lawnmower. The maintenance of ratoon rice used the method of Dong et al. (2017) using $\mathrm{N}$, $\mathrm{P}$, and $\mathrm{K}$ fertilizers, however, this experiment was modified by enriching with liquid compost extract. The liquid compost extract was applied every two weeks with a dose of 2 L.ha $^{-1}$ from the age of ratoon rice reaching seven days after harvest (DAH) until the harvest. Observations of arthropods were carried out in the main and ratoon rice after using bioinsecticides and abamectin. The growth and yield components parameters measured were plant height, tillers/hill at booting stage, productive tiller, shoot dry weight, length of panicle, grains per panicle, filled grain, empty grain, weight of 1,000 grains.

\section{Manufacture and application of bioinsecticides}

Beauveria bassiana and M. anisopliae used in this study as a result of the exploration of Safitri et al. (2018) in South Sumatra swampland, while $C$. militaris from the exploration in Central Kalimantan. The fungus identification was carried out by Dr. Suwandi, a microbiologist of the Department of Plant Pest and Disease, Faculty of Agriculture, Sriwijaya University, Palembang, Indonesia. B. bassiana, M. anisopliae, and $C$. militaris were first propagated on solid media, Sabouraud Dextrose Agar (SDA, Merck) following the method of Herlinda et al. (2018b). The fungus culture was incubated for 10 days and then transferred to liquid media, Sabouraud Dextrose Broth (SDB, Merck) following the method. The liquid culture of the fungus was incubated on top of the shaker moved at a speed of $120 \mathrm{rpm}$ for 7 days. Bioinsecticide is made according to the method of Mascarin et al. (2015). Bioinsecticide was made using a carrier of the liquid compost extract taken from shrimp skin, while the active ingredient was liquid entomopathogenic fungal culture, and added with vegetable oil. One liter of bioinsecticide contained $400 \mathrm{~mL}$ of the compost extract, $600 \mathrm{~mL}$ of liquid culture of entomopathogenic fungi, and $10 \mathrm{~mL}$ of vegetable oil. The utilized compost extract was first sterilized in the autoclave for 2 hours with a pressure of $1 \mathrm{~atm}$.

The bioinsecticide that was made was calculated for its conidia density after 7 days later. If it reached a minimum of $1 \times 10^{9}$ conidia. $\mathrm{mL}^{-1}$, it was applied. The calculation used the method of Herlinda et al. (2018b). Each 
bioinsecticide was sprayed on the rice canopy at a dose of 2 L.ha- ${ }^{-1}$ per application. Bioinsecticide spraying was conducted at $4.00-6.00$ p.m. to prevent conidia from being killed by ultraviolet irradiance. Abamectin plots sprayed with recommended abamectin were carried out in the morning on the same day of spraying bioinsecticides. For the main rice, spraying was carried out starting at rice aged $13,27,41,55,69$, and 83 DAT. For the ratoon rice, the spraying was carried out at $6,13,20,27,34,41,48,55$, and 62 DAH. The day after the application of the bioinsecticides and abamectin, the arthropods sampling in rice canopy was carried out.

\section{Arthropod sampling}

Sampling of the arboreal arthropods used a sweep net following the method of Herlinda et al. (2018a). The sampling of the arthropods was carried out in each treatment plot at 6.00-7.00 a.m. and it was repeated five times. The sampling of the ratoon rice was carried out during the age of $14,28,42,56,70$, and 84 DAT, while that of ratoon rice was carried out at 7, 14, 21, 28, 35, 42, 49, 56, and 63 DAH. During the sampling, a net sweep was intentionally applied to a rice stem with $\pm 30 \mathrm{~cm}$ depth from the canopy surface to obtain a sample representing the population.

The arthropods taken from the rice fields were cleaned and put into a vial bottle containing $96 \%$ ethanol and labeled. The arthropods were identified at the Laboratory of Entomology of the Department of Pest and Plant Disease, Faculty of Agriculture, Universitas Sriwijaya, Palembang, Indonesia. Identification of spiders referred to Barrion and Litsinger (1995) and identification of insects used Heinrichs (1994), Kalshoven (1981), and McAlpine et al. (1987). The results of the identification were verified and validated by Dr. Chandra Irsan, an arthropod taxonomist of Universitas Sriwijaya, Palembang, Indonesia.

\section{Data analysis}

The data on species of arthropods were classified according to functional groups (guild groups) consisting of herbivore insects, predators, parasitoid, and neutral insects following the Settle et al method. (1996). They were displayed in the form of tables or graphs. The difference in abundance of the herbivores, predators, parasitoid, or neutral between treatments was analyzed using ANOVA. If differences were found between treatments, it was then continued with HSD at $\mathrm{P}=0.05$. The data was calculated using the Software Program of SAS University Edition 2.7 9.4 M5.

\section{RESULTS AND DISCUSSION}

\section{Main and ratoon rice for niches and habitats of arthropods}

Local farmers generally use tile planting spacing (25 $\mathrm{cm} \times 25 \mathrm{~cm}$ ), but in this study, we introduced them to jajar legowo row spacing. With this spacing, the rice yielded uniform and regular rice growth, and pithy fruit visible from the stalk ducking down (Figure 1). The growth and development of ratoon rice were not inferior to the main rice (Figures 2 and 3), but the schedule of each stage of their growth was different between the main and ratoon rice (Table 1). In ratoon rice, its maturity per clump was less simultaneous when compared to the main rice (Figure 3 ). The observation of the growth and development of the main and ratoon rice was carried out to ascertain a link between phenology of rice and the abundance of arthropods in each stage of rice. The main and ratoon rice acted as niches providing food resources (for preys, hosts, and breed), and as habitats for shelter. This interesting phenomenon from the phenology observation showed that in ratoon rice there was abundance of rice earhead bugs, the Leptocorisa acuta being higher than that in the main rice. L. acuta was most abundant when the rice was ripe. The symptom of its attack was that the rice grains got deflated and brown spots (Figure 4).

\section{Arboreal arthropod abundance}

The ANOVA results showed that the abundance of predators in plots applied by bioinsecticide was higher and significantly different from the abundance in plots of abamectin (Table 2). The same trend also occurred in other guilds, that is the abundance of differences in parasitoids and herbivores was higher in bioinsecticide plots and significantly different from the abundance in plots of abamectin. Based on the stage of rice, the abundance of arthropods was also higher in plots applied by bioinsecticides than in abamectin plots (Figure 5). In the main rice, the abundance of arthropods reached the highest when the rice was at $42 \mathrm{DAT}$, while in the ratoon rice it was at 35 DAH.

Based on the guild group in Figure 6, the abundance of herbivore insects continued to increase with the increase of the rice age and peak in 56 DAT for main rice and $35 \mathrm{DAH}$ for ratoon. An interesting phenomenon occurred in all bioinsecticide plots (Figures 6), the increasing abundance of the herbivores was followed by an increase of the abundance of the predatory arthropods, and the abundance of the predatory arthropods continued to increase until the main rice got harvested. However, in abamectin plots, the predatory arthropods were only able to compensate for the increase in herbivore abundance in major rice insects, whereas in ratoon rice the abundance of predatory arthropods continued to decline, while the abundance of herbivore insects was increasingly dominant. The abundance of the predatory arthropods in bioinsecticide plots of B. bassiana, M. anisopliae, and C. militaris was higher than that in plots of abamectin. Predatory arthropods were most abundant in main rice, while the herbivore was the most dominant insect in ratoon rice. Predatory arthropods dominant in the main rice were tetragnathid spiders, while herbivore was the dominant insect in ratoon rice, L. acuta.

\section{Predatory arthropod abundance}

Predatory arthropods were grouped into spiders and predatory insects. The spiders obtained in this study consisted of 8 families, namely Araneidae, Linyphiidae, Lycosidae, Oxyopidae, Salticidae, Theridiidae, 
Tetragnathidae, and Theridiosomatidae (Figure 7). The abundance of spiders in the main paddy field reached its peak before the harvest ( 84 DAT), and in the ratoon rice, it reached a peak at 56-63 DAH. The most dominant tetragnathid spiders were found in all research plots in the main rice, while the most dominant salticid spiders were found in ratoon rice. There was a change in the composition of spiders dominant in the main and ratoon rice. The lowest abundance of spiders in the main and ratoon rice was found in plots applied by abamectin, while in the plots of three types of bioinsecticides the abundance of spiders tended to be all high. The lower in abundance of all spider families showed that the spiders were not resistant to abamectin.

Table 1. Rice growth and development stages in main and ratoon rice

\begin{tabular}{lcc}
\hline \multicolumn{1}{c}{ Rice stages } & $\begin{array}{c}\text { Main rice } \\
\text { age (DAT) }\end{array}$ & $\begin{array}{c}\text { Ratoon rice } \\
\text { age (DAH) }\end{array}$ \\
\hline Vegetative stage & $7-35$ & $7-21$ \\
Panicle forming and flowering stage & $42-56$ & $21-28$ \\
Milky stage & $56-70$ & $28-35$ \\
Dough stage & $70-84$ & $35-49$ \\
Ripening stage & $84-100$ & $49-63$ \\
\hline
\end{tabular}

Table 2. Arthropod abundance in main and ratoon rice applied with bioinsecticides of Beauveria bassiana, Metarhizium anisopliae, Cordyceps militaris, and abamectin

\begin{tabular}{|c|c|c|c|c|c|c|c|c|}
\hline \multirow{3}{*}{ Insecticides } & \multicolumn{8}{|c|}{ Arthropod abundance (individuals/5 nets) } \\
\hline & \multicolumn{2}{|c|}{ Predatory Arthropods } & \multicolumn{2}{|c|}{ Herbivore insects } & \multicolumn{2}{|c|}{ Parasitoids } & \multicolumn{2}{|c|}{ Neutral insect } \\
\hline & Main rice & Ratoon rice & Main rice & Ratoon rice & Main rice & Ratoon rice & Main rice & Ratoon rice \\
\hline B. bassiana & $21.50^{\mathrm{b}}$ & $10.89^{\mathrm{b}}$ & $16.83^{\mathrm{c}}$ & $22.00^{\mathrm{b}}$ & $5.16^{\mathrm{b}}$ & $3.11^{\mathrm{a}}$ & $4.33^{\mathrm{a}}$ & $1.11^{\mathrm{a}}$ \\
\hline M. anisopliae & $19.00^{\mathrm{b}}$ & $10.56^{\mathrm{b}}$ & $16.33^{\mathrm{bc}}$ & $24.33^{b c}$ & $2.83^{\mathrm{ab}}$ & $2.56^{\mathrm{a}}$ & $4.66^{\mathrm{a}}$ & $1.33^{\mathrm{a}}$ \\
\hline C. militaris & $19.67^{\mathrm{b}}$ & $10.78^{\mathrm{b}}$ & $16.00^{\mathrm{b}}$ & $26.00^{c}$ & $6.50^{\mathrm{b}}$ & $3.00^{\mathrm{a}}$ & $1.83^{\mathrm{a}}$ & $1.67^{\mathrm{a}}$ \\
\hline Abamectin & $11.50^{\mathrm{a}}$ & $5.22^{\mathrm{a}}$ & $11.17^{\mathrm{a}}$ & $14.22^{\mathrm{a}}$ & $0.66^{\mathrm{a}}$ & $1.33^{\mathrm{a}}$ & $2 . .00^{\mathrm{a}}$ & 0.89 \\
\hline ANOVA F-value & $10.17 *$ & $66.45^{*}$ & $22.32 *$ & $35.17 *$ & $12.84 *$ & $3.03 *$ & 4.95 & 1.24 \\
\hline $\mathrm{P}$ value $(0.05)$ & 0.00 & 0.00 & 0.00 & 0.00 & 0.00 & 0.05 & 0.01 & 0.32 \\
\hline Tukey's HSD test & 0.16 & 0.13 & 0.33 & 0.10 & 0.19 & 0.13 & 0.16 & 0.12 \\
\hline
\end{tabular}

Note: $*$ = significantly different; values within a column followed by the same letters were not significantly different at $\mathrm{P}<0.05$ according to Tukey's HSD test.

Table 3. Growth and yield parameters in main rice and ratoon rice applied with bioinsecticides of Beauveria bassiana, Metarhizium anisopliae, Cordyceps militaris, and abamectin

\begin{tabular}{|c|c|c|c|c|c|c|c|}
\hline \multirow{2}{*}{ Growth and yield components } & \multicolumn{4}{|c|}{ Insecticides } & \multirow{2}{*}{$\begin{array}{c}\text { ANOVA } \\
\text { F-value }\end{array}$} & \multirow{2}{*}{$\begin{array}{c}\text { P value } \\
(0.05)\end{array}$} & \multirow{2}{*}{$\begin{array}{l}\text { Tukey's } \\
\text { HSD test }\end{array}$} \\
\hline & B. bassiana & M. anisopliae & C. militaris & Abamectin & & & \\
\hline \multicolumn{8}{|c|}{ 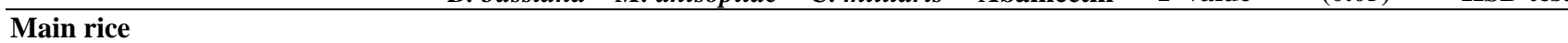 } \\
\hline Plant height $(\mathrm{cm})$ & $107.24^{\mathrm{ab}}$ & $105.88^{\mathrm{a}}$ & $108.04^{\mathrm{ab}}$ & $113.68^{b}$ & $3.42 *$ & 0.05 & 7.79 \\
\hline Tillers/hill at booting stage & $16.88^{\mathrm{a}}$ & $18.52^{\mathrm{a}}$ & $16.36^{\mathrm{a}}$ & $23.56^{\mathrm{b}}$ & $22.24 *$ & 0.00 & 2.79 \\
\hline Productive tiller (Tillers/hill) & $16.96^{\mathrm{a}}$ & $17.2^{\mathrm{a}}$ & $15.24^{\mathrm{a}}$ & $22^{\mathrm{a}}$ & $20.33^{*}$ & 0.00 & 2.69 \\
\hline Shoot dry weight (g) & $29.80^{\mathrm{a}}$ & $32.82^{\mathrm{a}}$ & $32.71^{\mathrm{a}}$ & $38.60^{\mathrm{b}}$ & $15.33^{*}$ & 0.00 & 21.94 \\
\hline Length of panicle $(\mathrm{cm})$ & $22.69^{\mathrm{ab}}$ & $22.05^{\mathrm{a}}$ & $22.49^{\mathrm{ab}}$ & $23.94^{\mathrm{b}}$ & $4.15^{*}$ & 0.03 & 1.67 \\
\hline Grains/panicle & 115.06 & 106.54 & 106.72 & 117.52 & 3.12 & 0.06 & - \\
\hline Filled grain (Grains/panicle) & $109.96^{\mathrm{ab}}$ & $101.56^{\mathrm{ab}}$ & $98.22^{\mathrm{a}}$ & $111.73^{\mathrm{b}}$ & $4.552 *$ & 0.02 & 12.81 \\
\hline Empty grain (Grains/panicle) & $5.10^{\mathrm{a}}$ & $4.98^{\mathrm{a}}$ & $8.49^{\mathrm{b}}$ & $5.78^{\mathrm{a}}$ & $8.17^{*}$ & 0.00 & 2.406 \\
\hline Weight of 1,000 grains & 24.98 & 21.71 & 26.14 & 22.62 & $3.191 *$ & 0.06 & - \\
\hline \multicolumn{8}{|l|}{ Ratoon rice } \\
\hline Plant height $(\mathrm{cm})$ & 110.92 & 107.44 & 109.24 & 105.84 & 0.57 & 0.64 & - \\
\hline Tillers/hill at booting stage & $19.94^{\mathrm{b}}$ & $18.75^{\mathrm{ab}}$ & $19.28^{\mathrm{ab}}$ & $16.23^{\mathrm{a}}$ & $4.73 *$ & 0.02 & 3.12 \\
\hline Productive tiller (Tillers/hill) & $17.84^{\mathrm{b}}$ & $16.28^{\mathrm{ab}}$ & $17.01^{\mathrm{b}}$ & $12.76^{\mathrm{a}}$ & $6.68 *$ & 0.00 & 3.63 \\
\hline Shoot dry weight $(\mathrm{g})$ & $29.80^{\mathrm{b}}$ & $28.55^{\mathrm{b}}$ & $24.94^{\mathrm{b}}$ & $17.67^{\mathrm{a}}$ & $20.76^{*}$ & 0.00 & 5.02 \\
\hline Length of panicle $(\mathrm{cm})$ & $21.06^{\mathrm{b}}$ & $18.94^{\mathrm{b}}$ & $19.36^{\mathrm{b}}$ & $16.4^{\mathrm{a}}$ & $21.69 *$ & 0.00 & 13.75 \\
\hline Grains/panicle & $80.09^{\mathrm{b}}$ & $78.08^{\mathrm{b}}$ & $69.33^{\mathrm{b}}$ & $46.78^{\mathrm{a}}$ & $21.69 *$ & 0.00 & 13.76 \\
\hline Filled grain (Grains/panicle) & $70.17^{\mathrm{b}}$ & $70.62^{\mathrm{b}}$ & $62.08^{\mathrm{b}}$ & $37.26^{\mathrm{a}}$ & $36.59 *$ & 0.00 & 10.88 \\
\hline Empty grain (Grains/panicle) & 7.90 & 7.78 & 10.58 & 9.52 & 1.85 & 0.19 & - \\
\hline Weight of 1,000 grains & $1.55^{\mathrm{b}}$ & $1.54^{\mathrm{b}}$ & $1.32^{\mathrm{b}}$ & $0.83^{\mathrm{a}}$ & $24.20 *$ & 0.00 & 0.29 \\
\hline
\end{tabular}

Note: $^{*}$ = significantly different; values within a row followed by the same letters were not significantly different at $\mathrm{P}<0.05$ according to Tukey's HSD test. 


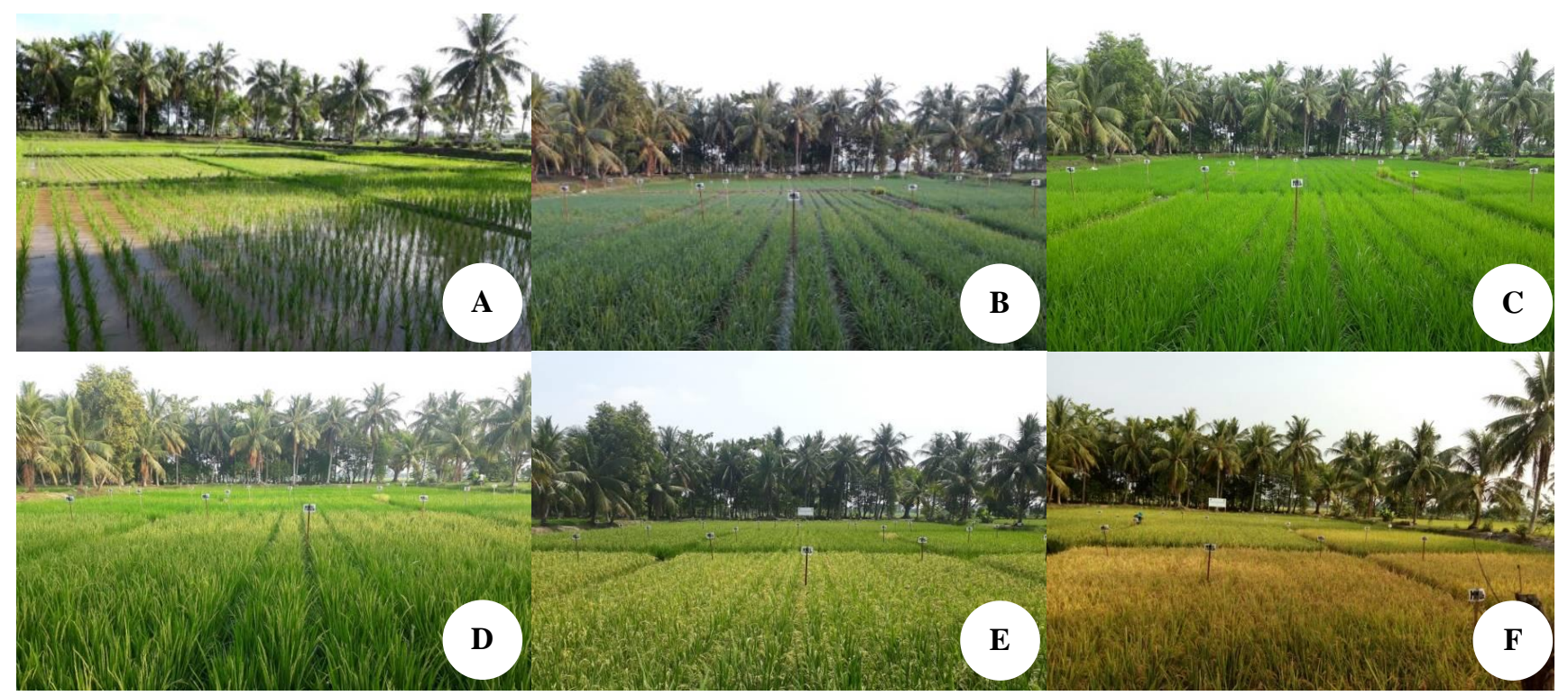

Figure 1. Main rice growth and development stages. A. 14 DAT, B. 28 DAT, C. 42 DAT, D. 56 DAT, E. 70 DAT, F. 84 DAT

There were 10 families of predatory insects found comprising Mantidae, Coenagrionidae, Staphylinidae, Anthicidae, Latridiidae, Formicidae, Coccinellidae, Tettigoniidae, Miridae, and Carabidae (Figure 8). There was a phenomenon similar to the lowest abundance of the spiders, namely the abundance of the predatory insects in the main and ratoon rice applied with abamectin, while in the plots of three kinds of bioinsecticides the abundance of spiders tended to be all high. However, among the 4 treatments, the plots applied with bioinsecticide of $B$. bassiana had the highest predatory abundance of insects. Coccinellid predators were the most dominant found in all plots of the main and ratoon rice. The abundance of the predatory insects in the main rice reached its peak during the milky stage (56 DAT) and in the ratoon it reached its peak when it was at $49 \mathrm{DAH}$.

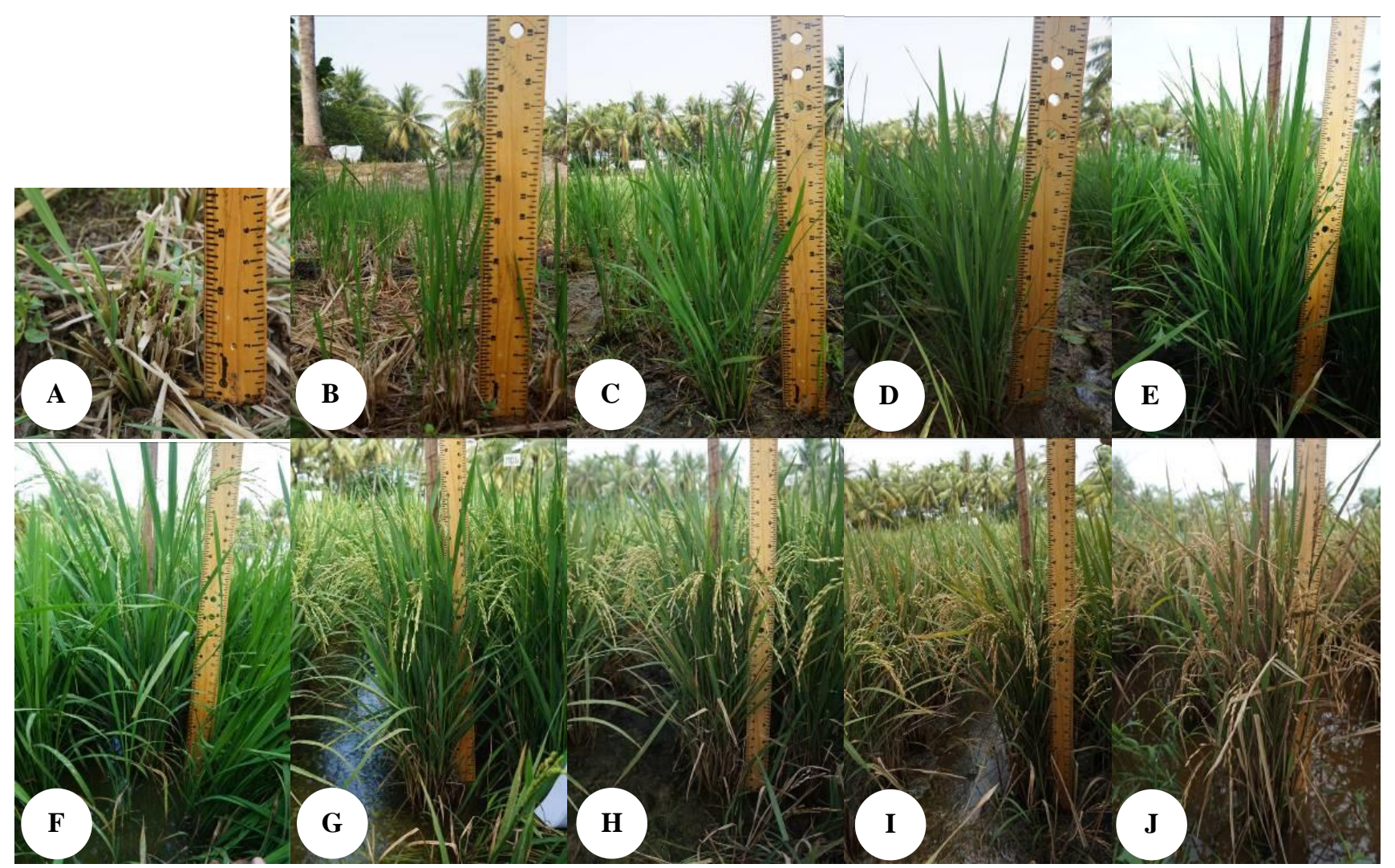

Figure 2. Ratoon rice growth. A. 2 DAH, B. 7 DAH, C. 14 DAH, D. 21 DAH, E. 28 DAH, F. 35 DAH, G. 42 DAH, H. 49 DAH, I. 56 DAH, J. 63 DAH 


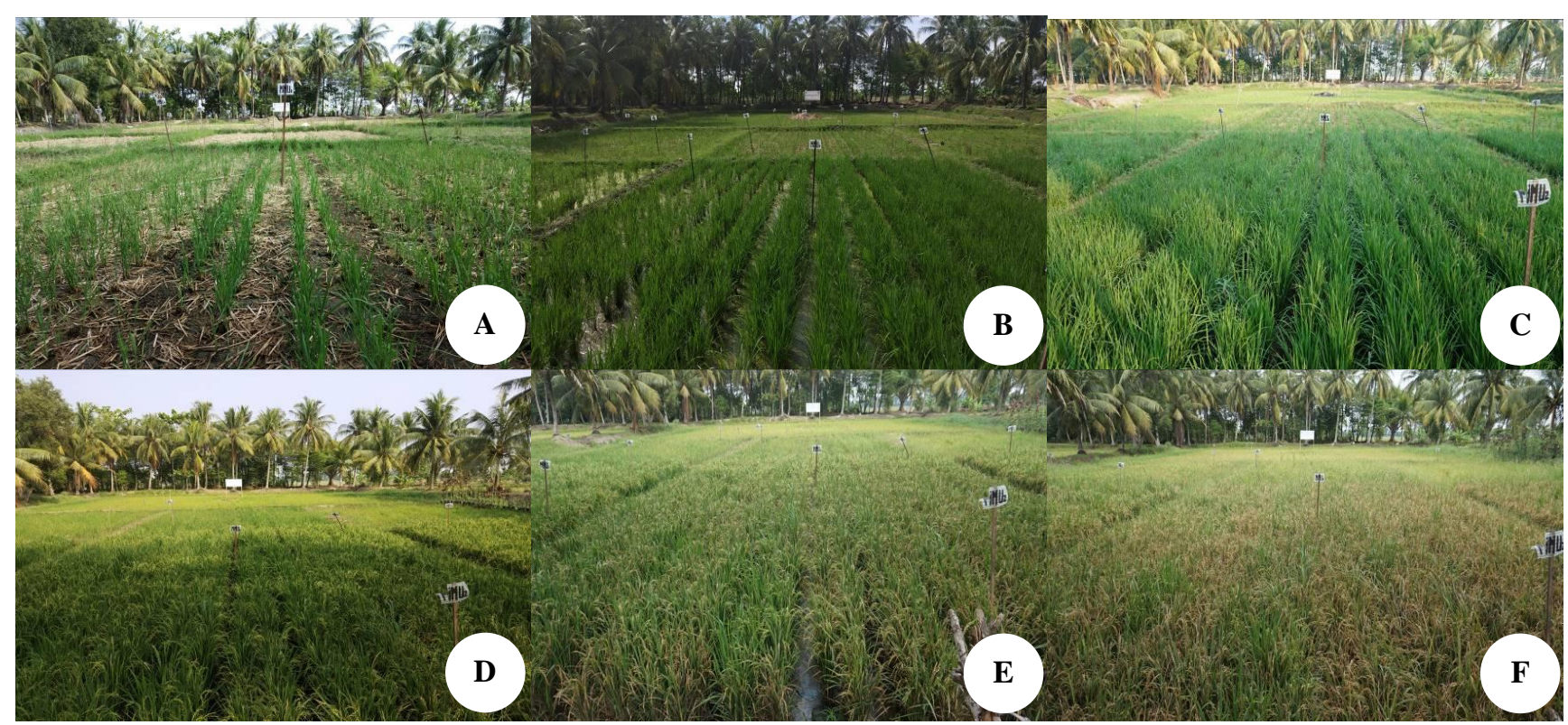

Figure 3. Ratoon rice growth and development stages

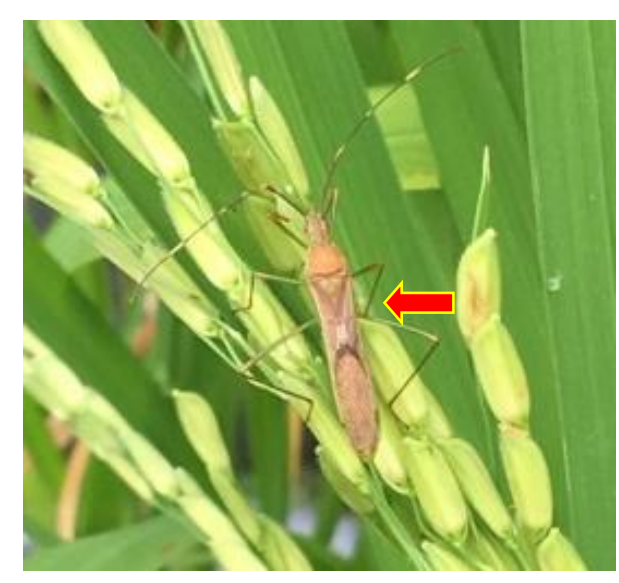

Figure 4. The earhead bugs (Leptocorisa acuta) and its symptom on rice grains showed by an arrow

Significant effects of fungal bioinsecticides and abamectin application in main rice were observed in plant height, tillers/hill at booting stage, shoot dry weight, length of panicle, filled grain, empty grain. The filled grain from plot applied with abamectin was significantly higher than other plots. While in ratoon rice, the fungal bioinsecticides application significantly increased length of panicle, grains/ panicle, filled grain, weight of 1,000 grains (Table 3).

\section{Discussion}

The abundance of arboreal arthropods in the bioinsecticide plots of $B$. bassiana, $M$. anisopliae, and $C$. militaris was higher than those of abamectin. This indicated that the fungal bioinsecticide did not reduce the abundance of arthropods, whereas abamectin could reduce arthropods from guilds of predator, parasitoids, herbivores. This is in line with the reports of Ananiev et al. (2002) that abamectin is wide spectrum activity. Sasmito et al. 2017) reported that abamectin could decrease abundance of BPH parasitoid (Anagrus nilaparvatae). The abamectin was proven to be able to reduce the abundance of arthropods in rice. While the entomopathogenic fungi had specific host insects, specifically the lepidopteran (Safitri et al. 2018; Ayudya et al. 2019), whereas in this study the dominant arthropods were spiders and insects of coleopteran. The entomopathogenic fungi were harmless to spiders (Yuliani 2016), Coleoptera (Ngin et al. 2017), and Hemiptera (Firouzbakht et al. 2015; Gholamzadeh-Chitgar et al. 2017).

The predatory arthropods were most abundant in all plots of main rice, whereas in ratoon rice was dominated by herbivore insects. The predatory arthropods, especially spiders, were more abundant in rice, especially before harvest because of the more complex the plant structure, the more various niches it provides (Settle et al. 1996; Rypstra et al. 1999; Sgolastra et al. 2016). In this study, herbivore insects dominate inhabiting in the ratoon rice field was due to the vast stretch of rice not as large as the main rice so that there was an increase in the density of the herbivore insects there. The most dominant species of herbivore insects was L. acuta.

The abundance of herbivore insects kept increasing with the increasing rice age and its peak at 56 DAT for the main rice and $35 \mathrm{DAH}$ for the ratoon rice because at that stage it was very appropriate for niches or food resources for the herbivore insects, namely milky stage. The increased abundance of the herbivores caused an increase in the abundance of the predatory arthropods. The predatory arthropods in rice were predators that played an important role in regulating the dynamics of herbivore insects populations (Seetle et al. 1996) so that they increased their predation once the prey population got increased which was called a good functional response (Karenina et al. 2019). 

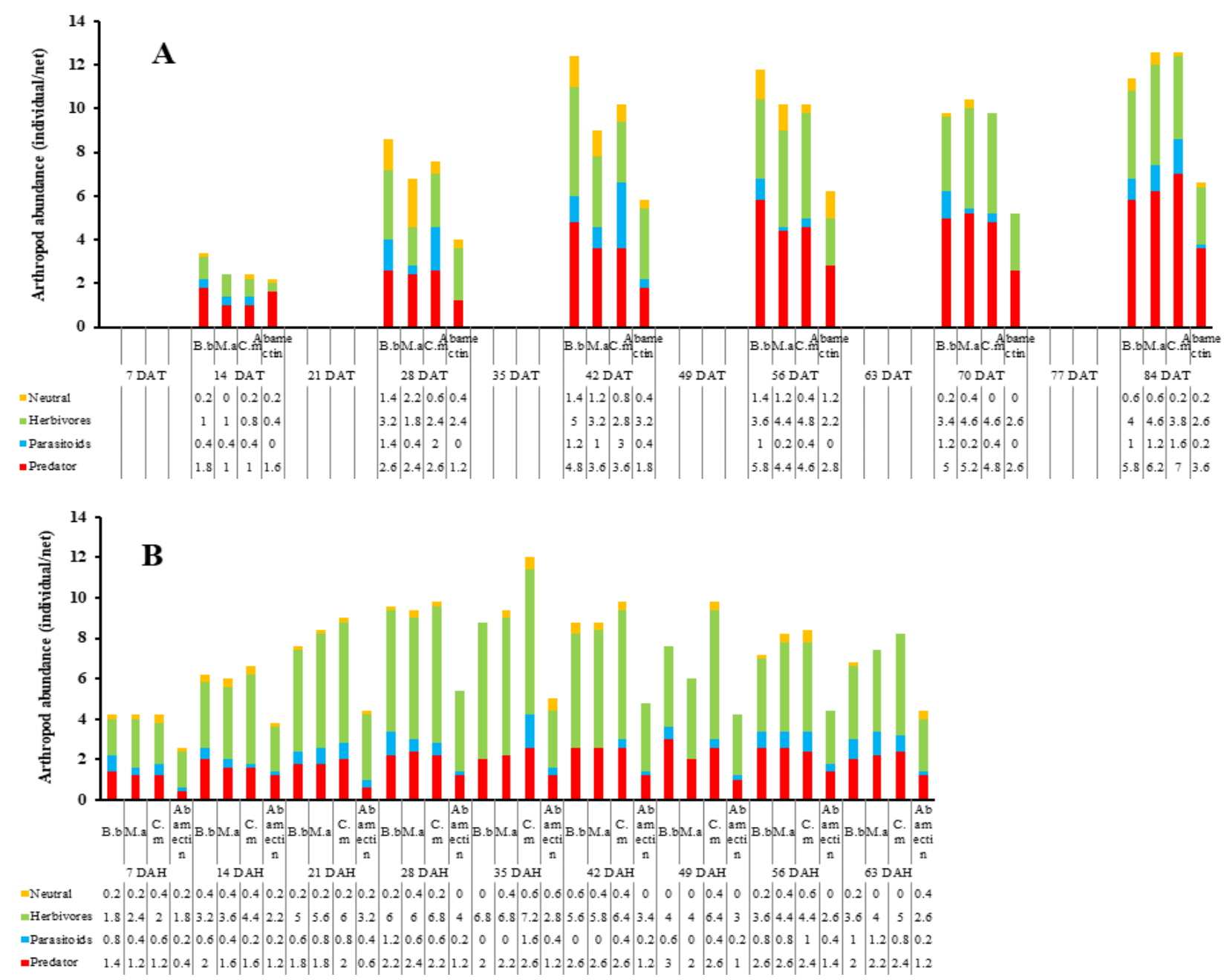

Figure 5. Arthropod abundance in main (A) and ratoon (B) rice applied with bioinsecticides of Beauveria bassiana, Metarhizium anisopliae, Cordyceps militaris, and abamectin

The abundance of spiders in the main rice reached its peak at 84 DAT and in the ratoon rice at 56-63 DAH, which was a ripening stage. The ripening stage is the peak of complex habitat and niches available for spiders (Rypstra et al. 1999). Spiders are generalist predators which prey on many species of herbivore insects and neutral insects (Seetle et al. 1996). In this study, the main predators of $\mathrm{BPH}$ were also found, namely Lycosidae which was able to catch its prey both on the ground and in the canopy (Ishijima et al. 2006). The families of spiders found in this study were arboreal spiders and they could be grouped into web-building spiders (Araneidae, Tetragnathidae, Linyphiidae, Theridiidae, and Theridiosomatidae) and non-web-building or hunting spiders (Lycosidae, Oxyopidae, Salticidae) (Gillespie 1999). The tetragnathid spiders were most dominant in the main rice, while salticid spiders were most dominant in the ratoon rice. There were changes in the composition of the dominance of the spiders on the main and ratoon rice. At the main rice harvest, tetragnathid spiders emigrated out of the rice fields, while salticid spiders entered the rice fields. When the main rice was harvested, the tetragnathid spiders which were web-building spiders migrated to the ratoon rice not as fast as the salticid spiders which were a hunting spider. The abundance of Araneidae, Tetragnathidae, Linyphiidae, Theridiidae, and Theridiosomatidae dropped dramatically in the plots that were applied abamectin because they formed a web that did not allow exposure to abamectin, while the hunting spiders (Lycosidae, Oxyopidae, Salticidae) still survived and tended to be more dominant in the plots that were applied to abamectin. Consequently, the abamectin affected worse on webbuilding spiders than on non-web-building spiders. Herlinda et al. (2018a) state that the abundance of webbuilding spiders can drop dramatically if in a rice field the insecticide is applied on a scheduled basis. 

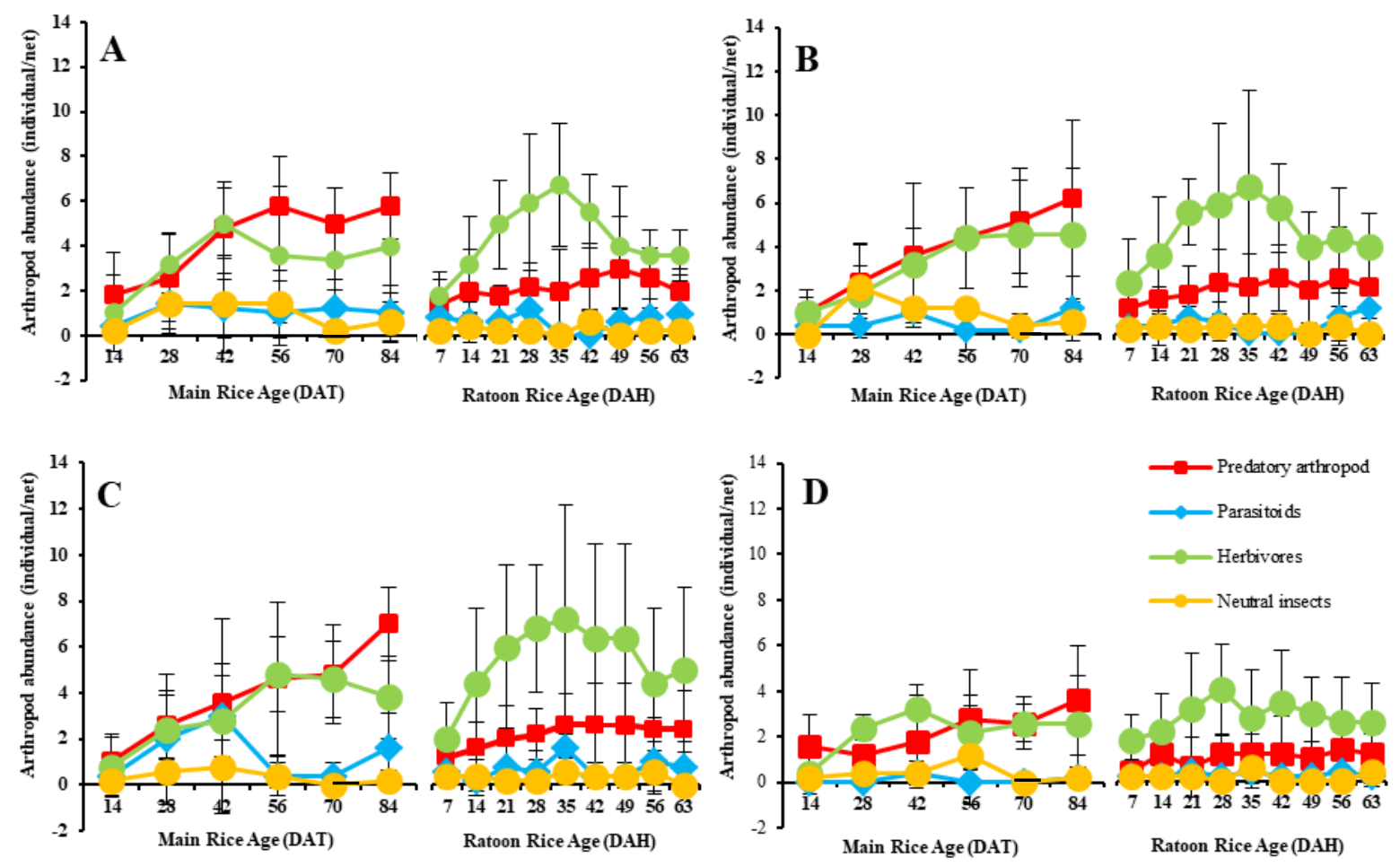

Figure 6. Arthropod guild composition in main and ratoon rice applied with bioinsecticides of Beauveria bassiana, Metarhizium anisopliae, Cordyceps militaris, and abamectin
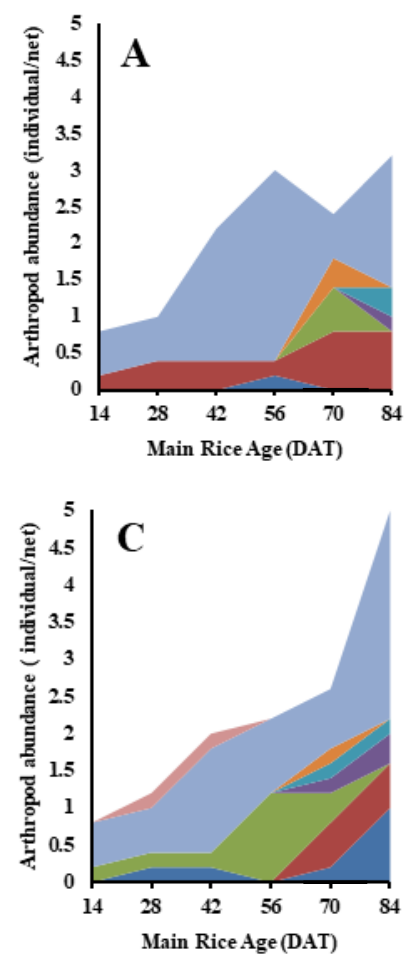
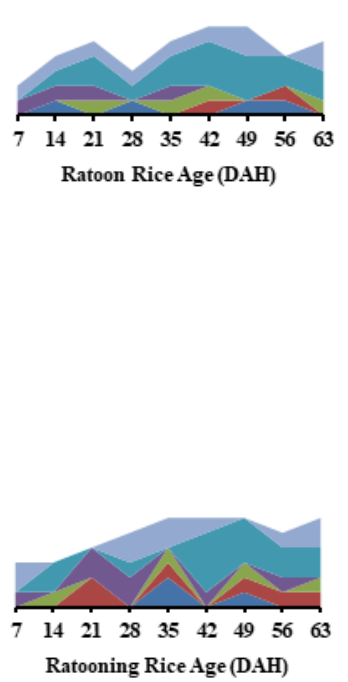
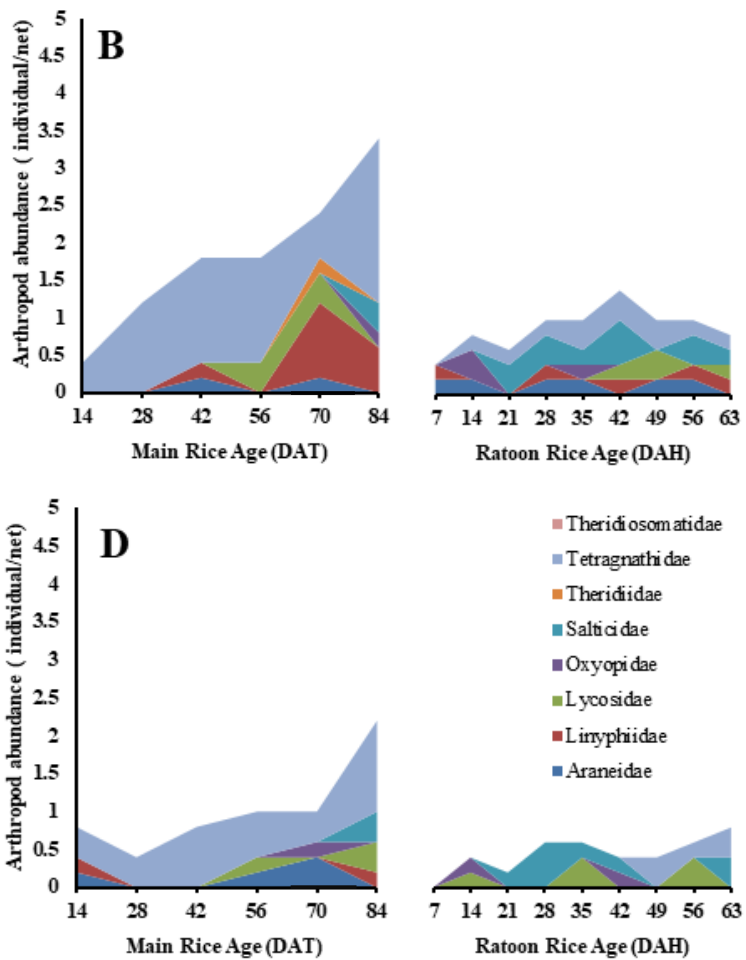

Figure 7. Spider community in main and ratoon rice applied with bioinsecticides of Beauveria bassiana, Metarhizium anisopliae, Cordyceps militaris, and abamectin 

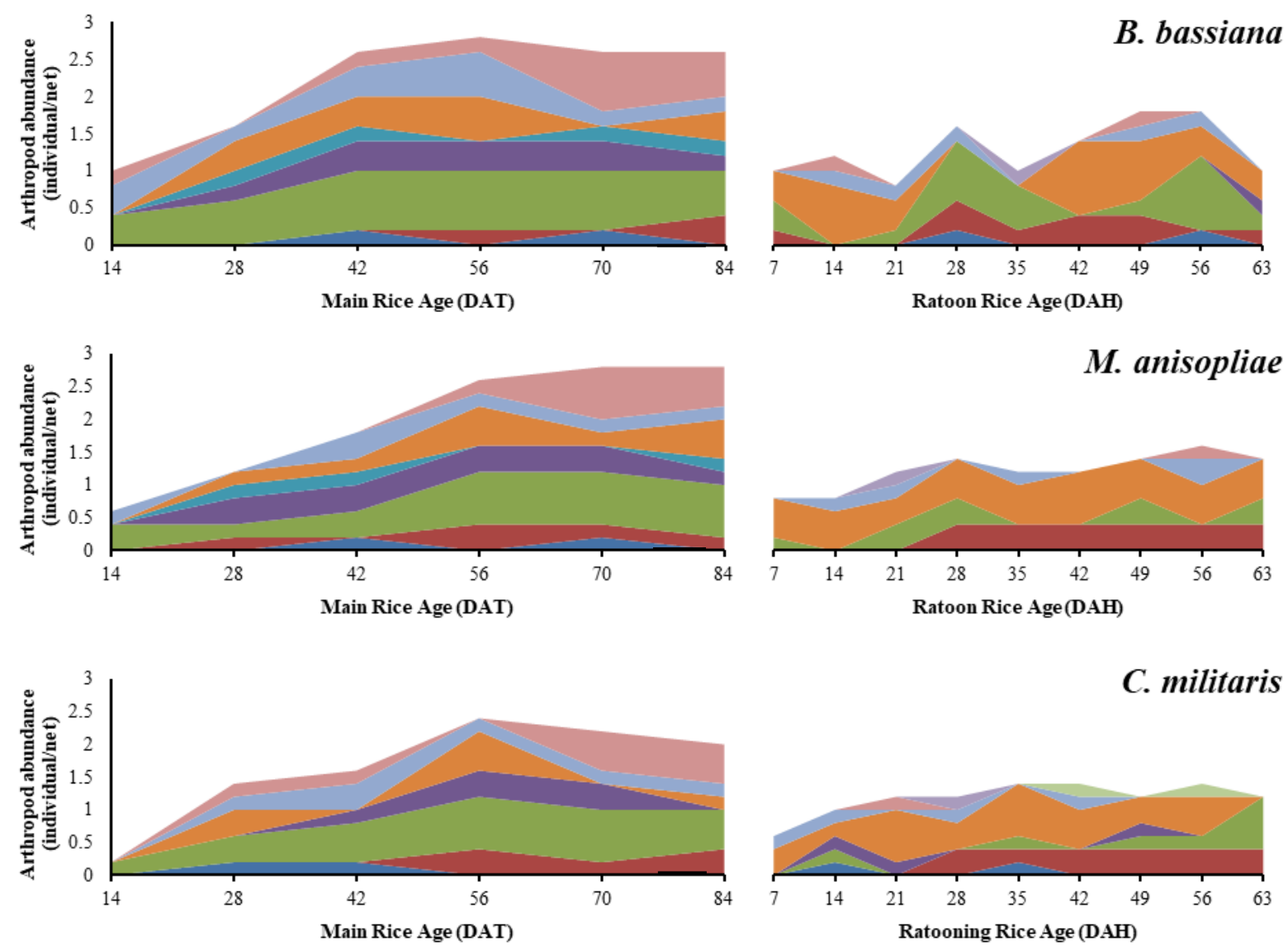

\section{C. militaris}
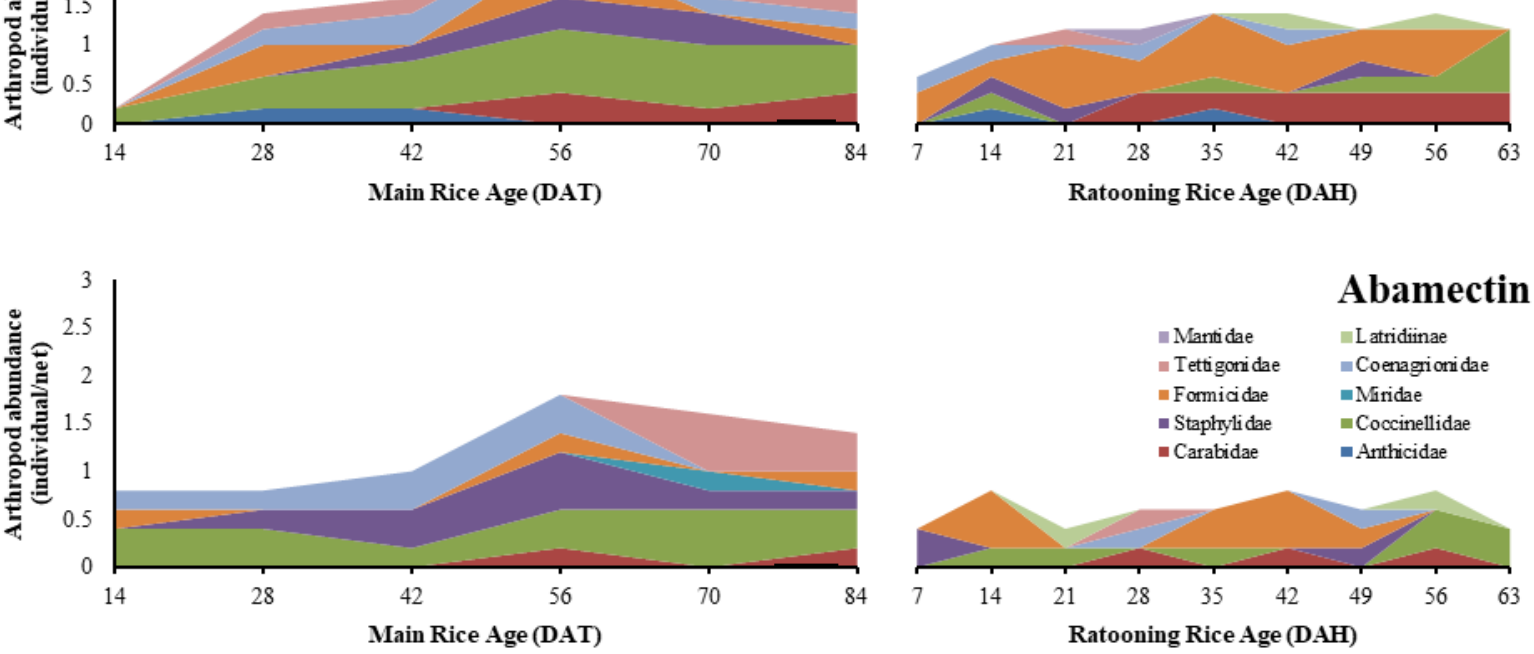

Figure 8. Predatory insect community in main and ratoon rice applied with bioinsecticides of Beauveria bassiana, Metarhizium anisopliae, Cordyceps militaris, and abamectin

The lowest abundance of predatory insects was found in the plots applied by abamectin, while in the plots of three types of bioinsecticides the abundance of spiders tended to be all high. Abamectin is broad spectrum insecticide that is a contact and stomach poison (Ananiev et al. 2002). Abamectin also works at the nerves system by stimulating gamma-aminobutyric acid (Pfeifer 1993). There was a decrease in the abundance of the predatory insects in the plots applied with this abamectin since the plots had a decreasing number of preys. The same is true for spiders, the predatory insects have functional responsiveness that follows the pattern of changes in their prey population (Karenina et al. 2019). The composition of families of predatory insects between the main and ratoon rice tended to be similar, however, the predatory abundance was higher in the main rice than those in the ratoon rice. Coccinellidae was the most dominant predatory insects found in all plots of main and ratoon rice because this beetle was a generalist predator capable of colonizing many habitats that provide many niches. Thus, the existence of ratoon rice became the habitats and niches for arthropods of the main rice, but the use of the abamectin could reduce the predatory abundance of arthropods. Finally, we conclude that abundance of arthropods was higher in main and ratoon rice applied with fungal bioinsecticides (B. bassiana, M. anisopliae, and $C$. militaris) than those applied with abamectin. The abundance of the parasitoids and the predatory arthropods was higher in main and ratoon rice applied with the fungal bioinsecticides. Abamectin could decrease abundance of parasitoids, predatory arthropods, and herbivores. 


\section{ACKNOWLEDGEMENTS}

This research was funded by the scheme of Magister Thesis Research (Penelitian Tesis Magister) with budget year of 2019 according to Directorate of Research and Community Service (DRPM), Directorate General for Research and Development, Indonesian Ministry of Research, Technology, and Higher Education, Contract Number: 096/SP2H/LT/DRPM/IV/2019.

\section{REFERENCES}

Ayudya DR, Herlinda S, Suwandi S. 2019. Insecticidal activity of culture filtrates from liquid medium of Beauveria bassiana isolates from South Sumatra (Indonesia) wetland soil against larvae of Spodoptera litura. Biodiversitas. 20: 2101-2109.

Ananiev EDK, Ananieva K, Abdulova G, Christova N, Videnova E. 2002. Effects of abamectin on protein and RNA synthesis in primary leaves of Cucurbita pepo L. (Zucchini). Bulg J Plant Physiol 28: 85-91.

Barrion A, Litsinger J. 1995. Riceland Spiders of South and Southeast Asia. Entomol IRRI, Philippines.

Dong H, Chen Q, Wang W, Peng S, Huang J, Cui K, Nie L. 2017. The growth and yield of a wet-seeded rice-ratoon rice system in Central China. Field Crops Res 208: 55-59.

Firouzbakht H, Zibaee A, Hoda H, Sohani MM. 2015. Virulence determination of Beauveria bassiana isolates on a predatory Hemipteran, Andrallus spinidens Fabricius (Hemiptera: Pentatomidae). Acta Phytopathol Entomol Hung 50: 115-125.

Gholamzadeh-Chitgar M, Hajizadeh J, Ghadamyari M, Karimi-Malati A, Hoda H. 2017. Effect of sublethal concentration of Beauveria bassiana fungus on demographic and some biochemical parameters of predatory bug, Andrallus spinidens Fabricius (Hemiptera: Pentatomidae) in laboratory conditions. Trakia J Sci 15: 160-167.

Gillespie RG. 1999. Comparison of rates of speciation in web-building and non-web-building groups within a Hawaiian spider radiation. $\mathbf{J}$ Arachnol 27: 79-85.

Heinrichs EA. 1994. Biology and Management of Rice Insect. IRRI, Philippines.

Herlinda S, Rizkie L, Suwandi, Susilawati, Lakitan B, Verawaty M, Hasbi. 2018a. Effects of high temperature and ultraviolet-C irradiance on conidial viability and density of Beauveria bassiana and Metarhizium anisopliae isolated from soils of lowland ecosystems in Indonesia. Eurasian J Anal Chem 13: 209-216.

Herlinda S, Yudha S, Thalib R, Khodijah, Suwandi, Lakitan B, Verawaty M. 2018b. Species richness and abundance of spiders inhabiting rice in fresh swamps and tidal lowlands in South Sumatera, Indonesia. J ISSAAS 24: 82-93.

Herlinda S, Yusticia SR, Irsan C, Hadi BAR, Lakitan B, Verawaty M, Hasbi. 2019. Abundance of arthropods inhabiting canopy of rice cultivated using different planting methods and varieties. J Biopest 12: 7-18.

Ishijima C, Taguchi A, Takagi M, Motobayashi T, Nakai M. Kunimi Y 2006. Observational evidence that the diet of wolf spiders (Araneae: Lycosidae) in paddies temporarily depends on dipterous insects. Appl Entomol Zool 41: 195-200.

Kalshoven LG. 1981. The Pest of Crops in Indonesia. Van Hoeve, Jakarta.

Karenina T, Herlinda S, Irsan C, Pujiastuti Y. 2019. Abundance and species diversity of predatory arthropods inhabiting rice of refuge habitats and synthetic insecticide application in freshwater swamps in South Sumatra, Indonesia. Biodiversitas. 20: 2375-2387.

Lakitan B, Lindiana L, Widuri LI, Kartika K, Siaga E, Meihana M, Wijaya A. 2019. Inclusive and ecologically-sound food crop cultivation at tropical non-tidal wetlands in Indonesia. Agrivita $\mathbf{J}$ Agric Sci 41: 23-31.

Lopes SF, Ramos MB, Almeida GR. 2017. The role of mountains as refugia for biodiversity in Brazilian Caatinga: conservationist implications. Trop Conserv Sci 10: 1-12.

Margono BA, Bwangoy JRB, Potapov PV, Hansen MC. 2014. Mapping wetlands in Indonesia using Landsat and PALSAR data-sets and derived topographical indices. Geo-Spat Inf Sci 17: 60-71.

Mascarin GM, Jackson MA, Kobori NN, Behle RW, Delalibera JÍ. 2015. Liquid culture fermentation for rapid production of desiccationtolerant blastospores of Beauveria bassiana and Isaria fumosorosea strains. J Invertebr Pathol 127: 11-20.

Mcalpine JF, Peterson BV, Shewel GE, Teskey HJ, Vockeroth JR, Wood DM. 1987. Manual of Nearctic Diptera. Agriculture Canada, Research Branch.

Mulyani A, Sarwani M. 2013. The characteristics and potential of suboptimal land for agricultural development in Indonesia. J Sumberdaya Lokal 7: 47-55. [Indonesian]

Ngin C, Suon S, Tanaka T, Yamauchi A, Kawakita K, Chiba S. 2017. Impact of insecticide applications on arthropod predators and plant feeders in Cambodian rice field. J Phytobiomes 1: 128-137.

Pfeifer K. 1993. Abamectin Avert Prescription Treatment 310. U.S. Environmental Protection Agency, California.

Rachmawati R, Kinoshita H, Nihira T, 2018. Production of insect toxin beauvericin from entomopathogenic fungi Cordyceps militaris by heterologous expression of global regulator. Agrivita J Agric Sci 4: 177-184.

Rypstra LA, Carter PE, Balfour RA, Marshall SD. 1999. Architectural features of agricultural habitats and their impact on the spider inhabitants. J Arachnol 27: 371-377.

Safitri A, Herlinda S, Setiawan A. 2018. Entomopathogenic fungi of soils of freshwater swamps, tidal lowlands, peatlands, and highlands of South Sumatra, Indonesia. Biodiversitas 19: 2365-2373.

Sasmito EK, Trisyono YA, Harjaka T. 2017. Impact of abamectin on Anagrus nilaparvatae, an egg parasitoid of Nilaparvata lugens. $\mathrm{J}$ Perlindungan Tanaman Indonesia 21: 80-86. [Indonesian]

Settle WH, Ariawan H, Astuti ET, Cahyana W, Hakim AL, Hindayana DH, Lestari AS. 1996. Managing tropical rice pests through conservation of generalist natural enemies and alternative prey. Ecology 77: 1975-1988.

Sgolastra F, Fisogni A, Quaranta M, Bogo G, Bortolotti L, Galloni M. 2016. Temporal activity patterns in a flower visitor community of Dictamnus albus in relation to some biotic and abiotic factors. Bull Insectol 69: 291-300.

Siaga E, Lakitan B, Hasbi H, Bernas SM, Widuri LI, Kartika K. 2019. Floating seedbed for preparing rice seedlings under unpredictable flooding occurrence at tropical riparian wetland. Bulg J Agric Sci 25(2): 326-336.

Sumikarsih E, Herlinda S, Pujiastuti Y. 2019. Conidial density and viability of Beauveria bassiana isolate from Java and Sumatra and their virulence against Nilaparvata lugens at different temperatures. Agrivita J Agric Sci 41: 335-349.

Suwandi, Ammar M, Irsan C. 2012. Application of extract compost increased yield and suppressed the diseases of ratoon rice crop in tidal swamp of Banyuasin Regency. J Lahan Suboptimal 1: 116-122. [Indonesian]

Yuliani D. 2016. Metarhizium anisopliae and Andrographis paniculata to non-target insect pests. J Ilmu Pertanian Indonesia 21: 20-25. [Indonesian] 